\title{
ПЕДАГОГИЧЕСКИЕ НАУКИ
}

УДК 779-16-85-50

ЭТНОКУЛЬТУРНОЕ ВОСПИТАНИЕ - ВАЖНЫЙ АСПЕКТ В ПЕДАГОГИКЕ

DOI: 10.31618/ESU.2413-9335.2021.2.85.1327

Имангаликова И.Б.,

Стариие преподаватели кафедры

Козлова Л.И., Лазарян Н.А.

Евразийский наџиональный университет имени Л.Н. Гумилева

Казахстан, г.Нур-Султан

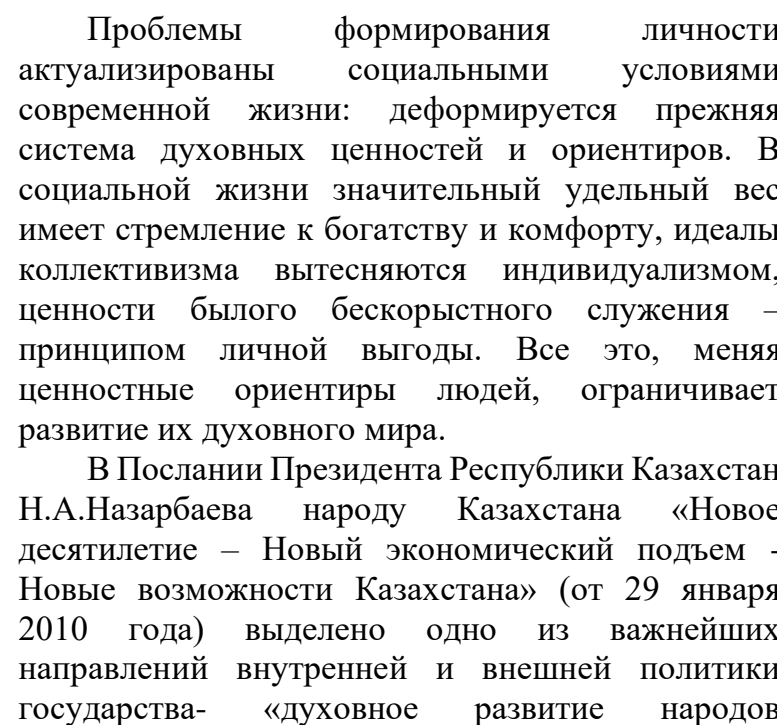
Казахстана, которое предусматривает поддержку развития культурных ценностей и традиций наших народов» $[1,2010 г]$.

В связи с этим не следует упускать из вида о народности и национальном характере образования, который является одним из главных принципов его развития. К.Д.Ушинский писал: «Воспитание, если оно не хочет быть бессильным, должно быть народным...», он высоко оценивал воспитательный потенциал народной педагогики. «Воспитание, созданное самим народом, основанное на народных началах, - писал он, имеет ту воспитательную силу, которой нет в самых лучших системах, основанных на абстрактных идеях...» [2, с.442]. Этнокультурное воспитание - это общественное воспитание. На протяжении всей истории человек был и остается объектом и субъектом воспитания. Накопленный опыт воспитания в сочетании с эмпирическими знаниями, проверенными на практике, составляет основу народной педагогики. Следует, однако, принять во внимание, что педагогическое воззрение народа, сложившееся без профессиональной педагогической подготовки, на основе лишь эмпирических знаний, носило в известной мере стихийный характер. Сам процесс воспитания, повседневный педагогический контакт с детьми не всегда был осознанным. В этих условиях порождает умение народа по крупицам отобрать все лучшее, разумное, отвечающее народному идеалу в воспитании настоящего человека. С этих позиций этнокультурное воспитание можно рассматривать как синтез всенародного педагогического творчества, как итог своеобразного исторического народного педагогического эксперимента. До сих пор являются поучительным, вдохновляющим примером выработанные народными воспитателям и приемы и методы трудового, нравственного, умственного, физического и эстетического воспитания.

Современное человечество представляет собой огромное множество различных исторически сложившихся общностей - наций, народностей, этнических групп. Каждая нация и народность отличается единством языка и культуры, имеет свои особенности в образе жизни, в образовании и воспитании. В условиях интернационализации и глобализации, политических и социальноэкономических реформ в Казахстане формируется своя воспитательно-образовательная ситуация, для которой характерно усиление этнизации содержания образования и воспитания, учет национальных особенностей культуры народов. Национальное своеобразие воспитания проявляется у каждого народа как свое отличительное, самобытное (культура, язык, обычаи, традиции). По сути - это культура межнационального общения, где признание, понимание, принятие особенностей каждого человека и народа в целом реализуются во взаимодействии, в информационной, коммуникативной сферах деятельности человека и передаче опыта и культурного наследия.

Общечеловеческие и национальные ценности находятся в неразрывном единстве, дополняют и обогащают друг друга, поэтому народное воспитание рассматривается как ценность общечеловеческого и национального характера. Народность должна быть ведущим принципом воспитания, ведь кто не принадлежит своему отечеству, тот не принадлежит человечеству. Здесь на помощь воспитателям приходит этнокультурное воспитание. Оно исследует закономерности и особенности народно-этнического воспитания, пользуется методами и источниками педагогики, но вместе с тем необходимо применение этнографических, археологических, этнопсихологических и социологических методов. Ориентация на общечеловеческие ценности, 
мировую и национальную культуры предполагает исследование педагогической культуры народных выработанной веками опытом человечества и успешно бытующей в народе до наших дней. На вопросы воспитания в духе народности, использования опыта народа, его воспитательного потенциала обращали внимание многие ученые в разные времена. Я.А. Коменский приложил много усилий для объединения народов Европы вокруг идей гуманизма и демократии [3, с.267]. Он утверждал, что учителя должны быть подлинно народными, их внимание должны привлекать национальные особенности учащихся, вопросы становления культурных общностей, общности исторических судеб людей. К.Д. Ушинский указывал на особенности в воспитании национального характера. Он писал, что школа должна действовать в направлении развития и изучения родного языка. В своей работе «О народности в общественном воспитании» отмечал, что в работе с детьми нужно стремиться давать учащимся как можно больше общечеловеческого, но через национальное [4, 161]. Созвучны высказыванию К.Д.Ушинского слова В.Г.Белинского, который говорил, что даже тогда, когда прогресс одного народа совершается через заимствование культуры у другого народа, он достигается национально. Когда же народ поддается напору чуждых ему идей и обычаев, не имея в себе силы перерабатывать их самодеятельностью собственной национальности в собственную сущность, тогда народ гибнет политически.

Вышеизложенный анализ и выделение особенностей этнокультурного воспитания будут

УДК 373.32

ГРНТИ 14.25.07 актуальными и при физической подготовке будущих специалистов. Происходящие в стране социально-экономические изменения, их сложность, противоречивость и недостаточная научная обоснованность обусловливают необходимость изменения образовательной стратегии в учебных заведениях. В ходе современных преобразований жизни, совершенствования социальных и политических отношений необходимы новые подходы к воспитанию личности учащейся молодежи, формирования основ гуманизма, нравственности, трудолюбия, ответственности, физического, социально-культурного развития, их целостного интегративного проявления. Это обостряет проблему формирования и развития духовности личности гражданина современного общества, приоритета духовного-нравственного воспитания.

\section{Список источников литературы:}

1. Послание Президента Республики Казахстан Н.А.Назарбаева народу Казахстана «Новое десятилетие - Новый экономический подъем - Новые возможности Казахстана» от 29 января 2010 года.

2. Ушинский, К.Д. Человек как предмет воспитания. Собр соч. - М. Л.; Издательство АПН РСФСР, 1952 - т.8 С.442

3. Коменский, Я. А. Избранные педагогические сочинения М.; 1955. - С. 267

4. Ушинский, К.Д. О народности в общественном воспитании. Пед. Соч. в 6 т. // Сост. С.Ф. Егоров. - М.; Педагогика, 1988 - т. 1 - С.161

\section{ФОРМИРОВАНИЕ ВЫЧИСЛИТЕЛЬНЫХ НАВЫКОВ У УЧАЩИХСЯ ПЕРВОГО КЛАССА}

\section{ФОРМИРОВАНИЕ ВЫЧИСЛИТЕЛЬНЫХ НАВЫКОВ У УЧАЩИХСЯ ПЕРВОГО КЛАССА}

Кравчук Кристина Алексеевна, студентка 3 курса гр. БА-НО-18 ТИ (ф) СВФУ в г. Нерюнгри Мамедова Лариса Викторовна, к.п.н., зав. кафедры ПиМНО ТИ (ф) СВФУ в г. Нерюнгри ТИ (Ф) СВФУ «Технический институт (филиал) федерального государственного автономного образовательного учреждения высшего образования «Северо-Восточный федеральный университет имени М.К. Аммосова», 2. Нерюнгри

\section{FORMATION OF COMPUTATIONAL SKILLS IN FIRST-GRADE STUDENTS}

Kravchuk K. A., Mamedova L. V. $T I(F)$ NEFU "Technical Institute (branch) of the Federal State Autonomous Educational Institution of Higher Education" North-Eastern Federal University named after M. K. Ammosov», Neryungri,

\section{АННОТАЦИЯ}

Формирование вычислительных навыков у первоклассников является одной из самых важнейших и главных задач начального обучения математике. Вычислительные навыки должны формироваться сознательно и прочно, так как они являются основой всего начального курса обучения математике. В связи с этим значительная часть заданий всех существующих на сегодняшний день учебников математики 